\title{
Job mobility in Europe, Japan and the U.S.
}

Citation for published version (APA):

Borghans, L., \& Golsteyn, B. H. H. (2011). Job mobility in Europe, Japan and the U.S. METEOR, Maastricht University School of Business and Economics. METEOR Research Memorandum No. 008 https://doi.org/10.26481/umamet.2011008

Document status and date:

Published: 01/01/2011

DOI:

10.26481/umamet.2011008

Document Version:

Publisher's PDF, also known as Version of record

\section{Please check the document version of this publication:}

- A submitted manuscript is the version of the article upon submission and before peer-review. There can be important differences between the submitted version and the official published version of record.

People interested in the research are advised to contact the author for the final version of the publication, or visit the DOI to the publisher's website.

- The final author version and the galley proof are versions of the publication after peer review.

- The final published version features the final layout of the paper including the volume, issue and page numbers.

Link to publication

\footnotetext{
General rights rights.

- You may freely distribute the URL identifying the publication in the public portal. please follow below link for the End User Agreement:

www.umlib.nl/taverne-license

Take down policy

If you believe that this document breaches copyright please contact us at:

repository@maastrichtuniversity.nl

providing details and we will investigate your claim.
}

Copyright and moral rights for the publications made accessible in the public portal are retained by the authors and/or other copyright owners and it is a condition of accessing publications that users recognise and abide by the legal requirements associated with these

- Users may download and print one copy of any publication from the public portal for the purpose of private study or research.

- You may not further distribute the material or use it for any profit-making activity or commercial gain

If the publication is distributed under the terms of Article $25 \mathrm{fa}$ of the Dutch Copyright Act, indicated by the "Taverne" license above, 


\section{Maastricht University}

Lex Borghans, Bart Golsteyn

J ob mobility in Europe, Japan and the US

$\mathrm{RM} / 11 / 008$

\section{METEOR}

Maastricht University School of Business and Economics

Maastricht Research School of Economics

of Technology and Organization

P.O. Box 616

NL - 6200 MD Maastricht

The Netherlands 
Job Mobility in Europe, Japan and the U.S. ${ }^{1}$

\author{
Lex Borghans ${ }^{2}$
}

Bart H.H. Golsteyn ${ }^{3}$

\begin{abstract}
Evidence about job mobility outside the U.S. is scarce and difficult to compare crossnationally because of non-uniform data. We document job mobility patterns of college graduates in their first three years in the labor market, using unique uniform data covering 11 European countries and Japan. Using the NLSY, we replicate the information in this survey to compare the results to the U.S. We find that (1) U.S. graduates hold more jobs than European graduates. (2) Contrasting conventional wisdom, job mobility in Japan is only somewhat lower than the European average. (3) There are large differences in job mobility within Europe.
\end{abstract}

Keywords: Job Mobility, Graduates, Europe, Japan, U.S.

JEL codes: J24, J31, I2

\footnotetext{
${ }^{1}$ This is a preprint of an article accepted for publication in the British Journal of Industrial Relations (Publisher: John Wiley \& Sons Ltd.) (C) Lex Borghans and Bart H.H. Golsteyn 2011. The authors received useful comments from the editor, two anonymous referees and seminar participants at the 2005 SOLE/EALE meeting in San Francisco, in particular Derek Neal, Jan van Ours and Donald Parsons. They also received detailed information about the labor market in Japan from Naoyuki Ogata and Yuki Inenaga.

${ }^{2}$ Department of Economics and the Research Centre for Education and the Labour Market (ROA), Maastricht University, lex.borghans@maastrichtuniversity.nl.

${ }^{3}$ Corresponding author. Department of Economics and the Research Centre for Education and the Labour Market (ROA), Maastricht University, and Swedish Institute for Social Research (SOFI), Stockholm University, b.golsteyn@,maastrichtuniversity.nl, Postal address: P.O. Box 616, 6200 MD, Maastricht, the Netherlands.
} 


\section{Introduction}

Job attachments are extremely fragile in the beginning of careers. Evidence for the U.S. shows that male workers hold on average 7 jobs in the first 10 years of their careers compared to 3 jobs in the remainder of their careers (Topel and Ward 1992). Job mobility has been related to wage changes and has been used as an indicator of labor market flexibility and the quality of the worker-job match. An important yet unanswered question is to what extent U.S. job mobility is representative for other countries. It is often claimed that job mobility in the U.S. is higher than job mobility in Europe and that job mobility in Japan is virtually absent. However, empirical evidence about job mobility outside the U.S. is scarce and it is difficult to compare findings across countries because of differences in data sources.

The aim of this paper is to document job mobility patterns in European countries, Japan and the U.S. We apply a unique uniform data set on college graduates' work experiences in the first 3 years after graduation from 11 European countries and Japan and compare the results with experiences from U.S. college graduates from the National Longitudinal Survey of Youth.

Our results indicate that in the European countries college graduates hold on average 1.6 jobs in the first three years after graduation. There are large differences in average job mobility within Europe, e.g. in Norway and the Netherlands graduates hold on average approximately half a job more than those in France, Sweden and Germany. In Japan mobility is with 1.4 jobs in three years only slightly less than the average European mobility. It is approximately equal to German and Swedish mobility and larger than 
French and Czech mobility (1.3). In the U.S., we find an average of 2.2 jobs held. This is far more than job mobility in any European country.

The paper is built up as follows. Section 2 discusses the literature on job mobility differences across countries. Section 3 introduces the data. Section 4 reports the job mobility patterns. Section 5 analyzes the composition of mobility and shows the robustness of the mobility indicators. Section 6 concludes.

\section{Evidence on job mobility patterns across countries}

Job mobility patterns in the U.S. have often been studied in the literature. Hall (1982) and Topel and Ward (1992) were among the first to investigate the patterns. They show that U.S. men hold approximately 10 jobs during their lifetime, with 7 jobs occurring in the first 10 years of their careers. Based on the NLSY, Light and McGarry (1998) find that white men have on average 1.23 job separations within two years after their entry to the labor market. This average rises to 2.53 separations after 4 years. Many other authors provide similar estimates of mobility patterns in the U.S.

There is a lacuna of empirical evidence about job mobility patterns outside the U.S. Some evidence is available for the U.K. and Germany. Using the British Household Panel Survey, Booth et al. (1999) find that in Britain men and women hold on average about 5 jobs during their lifetimes, half of these occurring in the first ten years of their careers. They find mobility in the U.K. to be approximately half the mobility in the U.S. Winkelmann (1994) shows that German men hold 4 jobs over their lifetime with 2 jobs in the first ten years of their careers. Using the British Household Panel Survey and the German Socio-Economic Panel, Dustmann and Pereira (2008) also show that mobility in 
Germany is smaller than mobility in the U.K. They find that British working men hold on average 4 jobs during the first ten years of their careers and German men 2.9 jobs. Their estimates after three years (2.2 jobs for the U.K. and 1.8 jobs for Germany) seem to be rather high compared to the estimates reported in other studies. However, using the IAB Beschäftigtenstichprobe (a one percent random sample from the German Social Security Record), Schönberg (2007) also finds that in Germany university graduates have held approximately 2 jobs 3 years after graduation. She finds that in the U.S., university graduates held more jobs over this period.

Van Ours (1990) shows for data from the 70s and 80s that mobility is large in the U.S. relative to European countries and Japan. His analysis also reports differences between some European countries. The data he used across countries are heterogeneous, including both surveys in which employers are asked about turnover and surveys in which workers are asked about their job changes. In this paper, we exploit the benefit of uniform data.

\section{Data}

To measure mobility, we use two data sets, (1) the CHEERS survey (Careers after Higher Education: a European Research Study), which includes data from the 1994/1995 cohort of graduates in 11 European countries and Japan (for more information, see http://www.uni-kassel.de/wz1/tseregs.htm) and (2) the 1979 Cohort of the National Longitudinal Survey of Youth (hereafter NLSY) for the US. We will discuss the selections in these data in turn. 


\subsection{CHEERS Survey}

The 1994/1995 graduate cohort from the CHEERS survey contains 36,697 graduates from 11 European countries and Japan. The graduates have obtained a Bachelor, Master or country-specific equivalent degree (e.g. Fachhochschulen in Germany, Grandes Ecoles in France and Hoger Beroeps Onderwijs in the Netherlands), either from a university or any other college for higher education. On average, countries approached the graduates three to four years after graduation.

The survey contains detailed questions about the experiences of graduates in the labor market. Central to the analysis are the questions about the labor market positions the graduates have held since graduation.

The graduates are asked which activity fits their current situation best and in which month and year they started this main activity. The answer categories are (1) paid job (including PhD-students since their position is considered a job in Europe), (2) selfemployed (including free-lance), (3) unemployed or searching for work, (4) education, (5) caring for children or other members of the household, (6) else.

Moreover, the graduates are asked to fill out a calendar based on the following question: "If you have changed activity since graduation in 1994/1995 (e.g. from "paid job" to "unemployed" or a change in employer, title of the function or job description), indicate in the schedule below your most important activities since graduation." In this calendar, the graduates can fill out up to five activities. For each activity the following data were gathered: Date (month and year) start activity; Date (month and year) end activity; Activity (paid job (including PhD-student), self-employed (including free-lance), unemployed or searching for work, education, caring for children or other members of 
the household, else). If the activity was a "paid job" or "self-employed", the graduate could in addition fill out whether the job was full-time or part-time and permanent or temporary. Also, the graduate was asked to give a job description.

We corrected the data for inconsistencies and made the following selections:

- If the job description was filled out, but there was no activity recorded, we recoded the activity to "paid job". This concerned 867 cases.

- 9,563 respondents filled out the same date and activity in the first question and in one of the five activities in the second question. To avoid double counting, the activity mentioned in the second question has been ignored in these cases. Next to this, 663 respondents filled out the same date but different activities in the first and second question. In this case, we recoded the answer to the second question to missing values. Third, 732 respondents filled out the same dates in the second question for more than one activity. In this case, we ignored the answer they filled out first.

- 1,002 graduates did not fill out the end date of their education. As this is the starting point of our analysis and we do not want to make assumptions about the end date of their education, we excluded these students from the analysis.

- 3,580 graduates did not fill out the date (month, year or both) of one or more of their activities. We excluded these graduates from the analysis.

- We are interested in job changes and not changes in types of contract. Therefore, if a change was recorded that had the same job description but only concerned a change in permanent/flexible (1,785 respondents) or part-time/full-time $(610$ respondents) contract, we ignored the change. 
- 1,242 graduates did not fill out any of the two questions concerning their activity after graduation. They were excluded from the analysis.

- 4,520 graduates were excluded because they continued in education.

After these selections, 26,353 graduates remain in our sample. With these data, we create a 36-months calendar which starts at graduation in which each month contains the activity of the graduate. The 36 months time limit is based on the minimum recorded time from graduation to the date the survey took place. Although some countries waited longer to approach the graduates, the timing of the period between graduation and the survey is in this way synchronized. We use this calendar to count the number of jobs a graduate has held during the 3 year period.

Respondents were asked to fill out only jobs that they had since graduation, but 8,406 respondents also added activities they had before the end of their education $(6,608$ reported one or more work activities before the end of the education). Jobs that start before graduation are counted as first jobs only if they continued after graduation (for a minimum of 1 month).

In the calendar we distinguish between employed and not employed and keep track of the count of the job, so we distinguish the statuses "not yet in a first job", "first job", "between first job and second job", etc. A respondent starts immediately with the "first job" status if he is employed before or at the date of his graduation in a job which he holds after graduation. 


\subsection{National Longitudinal Survey of Youth}

Our main objective in analyzing U.S. mobility is to optimize the comparability with the data we have for Europe and Japan. ${ }^{i}$ We therefore analyze U.S. data in which we make selections so that the data become comparable with the European and Japanese data. We use the NLSY, since this is the most frequently used source for analyses of U.S. mobility patterns (other sources frequently used are the Longitudinal Employer Employee Survey, Panel Study of Income Dynamics and the CPS).

The NLSY is a panel survey in which 12,686 respondents aged 14-22 in 1979 are followed from 1979 to $2002.50 .5 \%$ are male. Except for the 14 and 22 year olds who account for respectively $7.5 \%$ and $3.4 \%$ of the sample, the amount of respondents is approximately equal across age categories. Until 1994, the respondents fill out the survey on a yearly basis, afterwards the survey is held biennially. We use the NLSY data from 1979 to 2002.

We begin by selecting the college graduates. Every time the respondents fill out the survey, they are asked to report the highest grade completed and if they completed the education in the year preceding the survey, they are asked the year and month at which they completed their highest grade. We select all graduates who indicate to have completed the 4th year of college or more in one of the years (we assume that completing the 4th year of college is equivalent to a bachelor degree). Our sample thereby reduces to 2,249 respondents.

Table 1 shows the average age at which the respondents graduate from their college education in comparison to the European graduates. The average age they completed their education is 25.6 years. This average age is about 1 year lower than the 
European average while in Japan the average age at graduation is 2.5 years lower than in the U.S. The average age is rather high in the European countries, notably in Finland and Norway. The table also shows the sample distribution of men and women per country and the sample sizes.

--Table 1--

To calculate the number of job changes, we use the Work History file. In this file, information about jobs that last nine weeks or more is transformed into weekly information since 1 January 1978. The file contains information about the 5 most recent jobs an individual has held during the survey year (in the survey, information about more than 5 jobs is asked but in the public data release, the number of jobs is limited to 5 because only $1 \%$ of the individuals had more than 5 jobs). We use the information on the start and stop dates of the jobs to calculate the number of job changes, the total amount of tenure and the unemployment spells.

Comparable with our treatment of the CHEERS data, we make a 3-year calendar in which our start date is the date at which the respondent graduates from his college education. In the U.S. calendar, we apply 4-weeks periods rather than months to follow the career patterns.

Due to attrition or temporary absence, respondents may have missings in some years. It is important for us to remove these respondents because including them may lead to an underestimation of the number of job changes. If a respondent did not have a valid interview date in the first, second or third year within the three years period of the 
calendar, we remove the case for all years. 900 people had not responded during one of the three occasions and are consequently excluded which leaves us with 1338 respondents.

\section{Job Mobility Patterns}

Graphs 1-13 show the job mobility patterns per country. The graphs present for each month since graduation the fraction of graduates in the different statuses: "not yet in a first job," "first job," "between first job and second job," etc.

The level of employment directly after graduation is much lower in European countries and the U.S. compared to employment in Japan. From $45 \%$ in Finland and Norway to $82 \%$ of the college graduates in France and almost $80 \%$ in the U.S. report not being employed in the first month after graduation. In Japan only approximately $15 \%$ of the graduates are not employed in the first month after graduation. The low employment after graduation decreases approximately linearly in the southern European countries Italy, Spain and France, where three years after graduation approximately $10 \%$ of the respondents still do not have a first job. In other countries like the U.K. and especially the Czech Republic many graduates are also not employed right after graduation but they find jobs within a few months. In the U.S. $17 \%$ of the graduates is not employed three years after graduation. These non-employment patterns show the enormous capital losses in some countries.

Table 2 shows that in the U.S., the number of non-employment spells is far greater than in the other countries. Within Europe, especially many Spanish, Finnish and Czech graduates report being not employed after their first jobs. 
--Table 2--

Regarding the mobility patterns, Japan stands out as the country in which most graduates have a job at the moment of graduation. However, contrary to conventional wisdom $34 \%$ has had more than 1 job after three years. $9 \%$ of the Japanese graduates held three jobs or more during the first 3 years in the labor market. The graph furthermore shows shocks every year. The reason for this is that the first of April is a crucial day in Japan. Students graduate at April 1 and Japanese firms hire most of their workers on this date. As a consequence, while most graduates start to work at April 1, many of the graduates who did not immediately find a job, have to wait a full year before they start to work. Apart from employment immediately after graduation, approximately half of all job changes occurs at the first of April.

In the U.S. young graduates change jobs most of all countries. Only about $19 \%$ of the graduates still have their first job after three years. Job mobility in European countries is much lower than mobility in the U.S. Within Europe, there are also considerable differences. In Italy, France, Germany, Austria, Sweden and the Czech Republic many graduates are still in their first jobs three years after graduation. In the Netherlands, Norway, the U.K. and Finland a smaller percentage of the respondents are in their first jobs.

--Graphs 1-13-- 
Table 3 reports the average number of jobs graduates have had since graduation. Taking into account all job changes we find that on average in all countries graduates have had 1.6 jobs in the first three years of their careers (also 1.6 for European countries only). Within Europe, Norway, the Netherlands, the UK and Finland have a high average mobility of over 1.75. In the Czech Republic and France mobility is low.

Interestingly, mobility in Japan is close to the European average and similar to mobility in Germany and Sweden. In the U.S., graduates have had approximately 0.6 more jobs than their European counterparts. The number of jobs found in the U.S. is close to Light and McGarry's (1998) findings who make comparable selections in their data. ${ }^{\text {ii }}$

--Table 3--

To check the sensitivity of our results, we report some variants in Table 3. First, in the CHEERS survey it is only possible to fill out up to 6 activities. Only $1.1 \%$ of the sample filled out all the available space for activities and is therefore potentially truncated. Because the proportion of respondents who have filled out all possible spots is small, it is unlikely that the results would have changed if it would have been possible to fill out more activities. However, because in the NLSY people can fill out up to 15 jobs, the reported amount of job changes in the U.S. could be affected. $4.8 \%$ of the NLSY respondents report to have had 6 jobs or more. Considering the higher average number of changes in the U.S. it is plausible that the part of the distribution that would surpass 6 job changes is greater than in Europe. Therefore truncating the U.S. sample to 6 jobs underestimates the number of job changes. However, if we truncate the number of jobs 
held, we find a number of jobs held of 2.20 , which is only marginally smaller than the non-truncated average.

As shown in the graphs, not all graduates have had a job after three years. One could argue that these graduates have withdrawn from the labor market. In the second column of Table 3 we therefore present mobility figures only for graduates who held at least one job during the three years under investigation. As expected, especially the job mobility figures for Spain and the U.S. are affected by this change in definition of mobility. In the other countries, the findings are affected only slightly.

The age at which people graduate varies substantially across countries (see table 1). Since the position in the labor market of older graduates might differ from the position of young graduates, we calculate mobility using only graduates younger than 35 or 30 at the moment of graduation. The third and fourth columns of Table 3 show that there are only some small changes in the number of jobs held when this restriction is applied. The findings are therefore only slightly affected by age.

Sex differentials are another potential concern. In many papers (Blau 1981; Blau and Kahn 1981; Keith and McWilliams 1995; Loprest 1992; Royalty 1998; Ruhm 1987), job mobility is analyzed separately for men and women. The main reason for differences in mobility patterns is that women could be less attached to the labor market. The fifth and sixth column of the table show for most countries small differences between the sexes. We find that female job mobility exceeds male mobility in Spain and Japan while men tend to be more mobile in the Czech Republic. However, these differences are very small. The maximum difference in mobility between sexes is 0.14 jobs. 


\section{The Composition of Job Mobility}

Changes between jobs can have different reasons and can be different in character. In Table 4 we report variants of mobility.

--Table 4--

\subsection{Substantial and minor job-to-job changes}

In some cases people will move from one job to a very similar other job, while in other cases people might change to very different jobs. Human capital will be more transferable when changes are minor than when changes are more substantial. For that reason Parent (2000) and Neal (1999) restrict their analyses to job changes with different 3-digit industrial codes. The Cheers data do not have industrial codes. To distinguish substantial job changes from minor changes we use a 3-digit occupational code. The advantage of using an occupational code rather than an industrial code is that the former may better reflect the tasks of a worker than an industrial code. Due to reporting errors and the influence of the specific classification, the distinction between moves with a change in occupation and moves to a similar occupation will not be perfect, but these figures will provide a reasonable impression about the character of the job mobility (McCall 1990). ${ }^{\mathrm{iii}}$ In the NLSY-analysis, we use the 1980 Census 3-digit codes and in 2002, the 2000 Census 3-digit codes.

The results indicate that, in Europe, approximately $50 \%$ of all job changes occurs between different 3-digit occupations. Also in Japan approximately half of the changes 
occurs between different 3-digit occupations. In the US, a much larger fraction of all job changes is between different 3-digit occupational codes.

\subsection{Voluntary and Involuntary Changes}

Another distinction can be made between voluntary and involuntary job changes.

Distinguishing empirically between voluntary and involuntary moves is often arbitrary, even if reasons are given by the respondent. Consider for instance the top-manager who leaves the firm "because it was time to move on." People could change job because they anticipate to be dismissed in the close future. For that reason, Light and McGarry (1998), Mincer and Jovanovic (1981) and Ruhm (1987) do not distinguish between voluntary and involuntary changes. Light and McGarry (1998) find no qualitative differences in their analysis for the whole sample and the voluntary job changers. However, other papers show that voluntary and involuntary job changes have a different impact on cumulative wages (Bartel and Borjas 1981; Booth et al. 1999) and thus, as Keith and McWilliams (1995) note, the aggregate cumulative mobility may disguise the offsetting effects of voluntary and involuntary mobility on subsequent wages.

In the NLSY, the respondents are asked to give the reason for a job change. The respondents could answer that they changed jobs for involuntary reasons (e.g. plant closed, discharged or fired, laid off), or for voluntary reasons (quit to take another job, pregnancy, quit to look for another job). Unfortunately, in the CHEERS data no question is asked concerning the reason for a job change.

A plausible proxy for the involuntariness of job change may be the time people are not employed after ending their job. In the NLSY, we find that graduates who state that 
they are fired need on average 11.2 weeks to find a new job. Graduates who quit their job because they take another job are on average not employed for 3.7 weeks. This is in line with findings by Keith and McWilliams (1995), who show that the probability that men had a new job lined up prior to discharges (13\%) and lay-offs $(23 \%)$ is much lower than that of men who quit for economic $(53 \%)$ or family related $(30 \%)$ reasons. We count a voluntary separation if the time between the separation of one job and the beginning of a new job, is less than 2 months. If it takes longer than 2 months to find a new job, the job separation is considered to be involuntary. The results remain similar for different cut-off points for the definition of voluntariness ( $\leq 2$ weeks, $\leq 4$ weeks).

The total number of separations is lower than the number of jobs because for the job that graduates are currently holding it is not known whether any separation will be voluntary or involuntary. In the third and fourth column of table 4 it is shown that the average number of voluntary job-separations is much larger than the number of involuntary separations. In fact, with the exception of the U.S., in most countries the number of involuntary separations is negligible compared to the voluntary separations. ${ }^{\text {iv }}$ We conclude therefore that our results seem to be more applicable to voluntary than to involuntary changes.

We find that involuntary job separations are relatively rare in Europe and Japan. The highest number of involuntary separations in Europe is found in Spain. Involuntary job changes in the U.S. occur much more frequently than in Japan and Europe. 


\section{Conclusions}

In this paper, we describe job mobility patterns of college graduates from 11 European countries, Japan and the U.S. during the first three years after graduation. Distinguishing states like "not yet in a first job," "first job," "not in a job after first job," "second job," we describe the development of graduates' careers.

Our main findings are that in the European countries college graduates on average hold 1.6 jobs in the first three years after their graduation. There are large differences in average job mobility within Europe, e.g. in Norway and the Netherlands graduates hold on average approximately half a job more than those in France, Sweden and Germany. In Japan mobility is with 1.4 jobs in three years only slightly lower than the average European mobility. It is approximately equal to German and Swedish mobility and larger than French and Czech mobility (1.3). In the U.S., we find an average of 2.2 jobs held. This is far more than mobility in any European country.

Our research has several limitations. First, although we tried to make the CHEERS and NLSY data set as comparable as possible, some differences might remain: in the CHEERS data PhD students are counted as workers while this is not the case in the NLSY data. We also use four years of attendance at university to define having a degree in the NLSY, yet there are students who take longer to complete their degree. Second, some evidence, e.g. Boeri (1996), shows that turnover may be related to the business cycle. This could affect our results because the CHEERS countries may have been in different phases of the cycle during the survey and because the CHEERS survey was taken at a different time than the NLSY. The CHEERS-survey interviews graduates who finished their education in 1994/95. In the U.S., graduates study on average until they are 
25 years of age, implying that they enter the labor market between 1982 (22 year olds in 1979) and 1990 (14 year olds in 1979). The labor market was considerably stronger in the mid-1990s in most of Europe than in the mid-1980s in the U.S. ${ }^{\mathrm{v}}$

For future research, it would be interesting to see whether our results extend to other graduates' job mobility than college graduates only and to track job changes beyond the first three years after graduation. In addition, it would be interesting to analyze the relationship between job mobility and business cycles. With the crosssectional CHEERS data set we cannot analyze this, but with longitudinal data this could be analyzed. Third, it would be interesting to analyze the causes of cross-national differences in job mobility. One potential cause could be that there are institutional differences between countries in the regulation of labor. These are often assumed to be an important factor causing differences in job mobility between countries and over time. Kambourov and Manovskii (2008) find that mobility increased sharply in the U.S. from 1966-1993. They propose that mobility in the U.S. may have increased over time because of "usual suspects such as technological change, globalization, international trade, changes in government regulation and labor force unionization" (p. 34). Harhoff and Kane (1997) argue that institutional characteristics of the German labor market restrict mobility. They point out institutional factors which might restrict mobility, including unionization and firing costs. The relationship between mobility and institutional differences could be analyzed using indicators from e.g. Botero et al. (2004) or Chor and Freeman (2005). We find no significant relationships between job mobility and their indicators of employment protection laws, collective relations laws, and social security laws. However, this may be due to our limited sample size. Fourth, it would be 
interesting to know more about the reasons for differences in voluntary and involuntary job separations.

\section{References}

Bartel, A. and Borjas, G. J. (1981). Wage Growth and Job Turnover: An Empirical Analysis. In: Studies in Labor Markets, ed. by Rosen, S., pp. 65-84. Chicago: University of Chicago Press.

Blau, F. D. (1981). Race and Sex Differentials in Quits by Young Workers. Industrial and Labor Relations Review, 34(4): 563-577.

Blau, F. D. and Kahn, L. M. (1981). Causes and Consequences of Layoffs. Economic Inquiry, 19(2): 270-296.

Boeri, T. (1996). Is Job Turnover Countercyclical? Journal of Labor Economics, 14(4): 603-625.

Booth, A., Francesconi, M. and Garcia-Serrano, C. (1999). Job Tenure and Job Mobility in Britain. Industrial and Labor Relations Review, 53(1): 43-70.

Botero, J., Djankov, S., La Porta, R., Lopez-de Silanes, F. and Shleifer, A. (2004). The Regulation of Labor. Quarterly Journal of Economics, 119(4): 1339-1382. 
Chor, D. and Freeman, R. B. (2005). The 2004 Global Labor Survey: Workplace Institutions and Practices Around the World. NBER Working Paper No. w11598.

Dustmann, C. and Pereira, S. C. (2008). Wage Growth and Job Mobility in the United Kingdom and Germany. Industrial and Labor Relations Review, 61(3): 374-393.

Hall, R. E. (1982). The Importance of Lifetime Jobs in the United States Economy. American Economic Review, 72(4): 716-724.

Harhoff, D. and Kane, T. (1997). Is the German Apprenticeship System a Panacea for the U.S. Labor Market? Journal of Population Economics, 10: 171-196.

Kambourov, G. and Manovskii, I. (2008). Rising Occupational and Industry Mobility in the United States: 1968-1997. International Economic Review, 49(1): 41-79.

Keith, K. and McWilliams, A. (1995). The Wage Effects of Cumulative Job Mobility. Industrial and Labor Relations Review, 49(1): 121-137.

Light, A. and McGarry, K. (1998). Job Change Patterns and the Wages of Young Men. The Review of Economics and Statistics, 80(2): 276-286.

Loprest, P. J. (1992). Gender Differences in Wage Growth and Job Mobility. American Economic Review Papers and Proceedings, 82(2): 526-532. 
McCall, B. P. (1990). Occupational Matching: A Test of Sorts. The Journal of Political Economy, 98(1): 45-69.

Mincer, J. and Jovanovic, B. (1981). Labor Mobility and Wages. In: Studies in Labor Markets, ed. by S. Rosen, pp. 21-63. Chicago: University of Chicago Press.

Neal, D. (1999). The Complexity of Job Mobility among Young Men. Journal of Labor Economics, 17(2): 237-261.

Parent, D. (2000). Industry-Specific Capital and the Wage Profile: Evidence from the National Longitudinal Survey of Youth and the Panel Study of Income Dynamics. Journal of Labor Economics, 18(2): 306-323.

Royalty, A. B. (1998). Job-to-Job and Job-to-Nonemployment Turnover by Gender and Education Level. Journal of Labor Economics, 16(2): 392-443.

Ruhm, C. J. (1987). The Economic Consequences of Labor Mobility. Industrial and Labor Relations Review, 41(1): 30-42.

Schönberg, U. (2007). Wage Growth due to Human Capital Accumulation and Job Search: a Comparison between the United States and Germany. Industrial and Labor Relations Review, 60: 562-586. 
Topel, R. H. and Ward, M. P. (1992). Job Mobility and the Careers of Young Men. The Quarterly Journal of Economics, 107(2): 439-479.

Van Ours, J. (1990). An International Comparitive Study on Job Mobility. Labour, 4(3): $33-55$.

Winkelmann, R. (1994). Count Data Models-Economic Theory and an Application to Labor Mobility, Lecture Notes in Economics and Mathematical Systems 410. Berlin: Springer-Verlag. 


\section{Graphs and Tables}

Table 1

Mean age at graduation, gender and sample size per country

\begin{tabular}{lrrrr}
\hline & $\begin{array}{r}\text { Mean age at } \\
\text { graduation }\end{array}$ & $\begin{array}{r}\text { Women } \\
\%\end{array}$ & $\begin{array}{r}\text { Men } \\
\%\end{array}$ & Sample \\
\hline Italy & & & & \\
Spain & 27.6 & 47.4 & 52.6 & 1914 \\
France & 24.4 & 54.4 & 45.6 & 1423 \\
Austria & 24.5 & 52.4 & 47.6 & 1628 \\
Germany & 27.8 & 46.0 & 54.0 & 1723 \\
Netherlands & 27.4 & 42.4 & 57.6 & 2798 \\
UK & 25.6 & 55.3 & 44.7 & 2487 \\
Finland & 25.7 & 57.6 & 42.4 & 2093 \\
Sweden & 28.5 & 59.8 & 40.2 & 2073 \\
Norway & 27.9 & 54.5 & 45.5 & 1928 \\
Czech Rep. & 28.6 & 59.9 & 40.1 & 2746 \\
Japan & 24.6 & 58.9 & 41.1 & 2764 \\
US & 23.1 & 46.0 & 54.0 & 2534 \\
& 25.6 & 52.8 & 47.2 & 1338 \\
\hline
\end{tabular}

Source: Cheers 1999 and NLSY 1979-2002. 
Table 2

Number of non-working spells after first job

\begin{tabular}{lrrrrr}
\hline & 0 & 1 & 2 & $3+$ & Total \\
\hline & & & & & \\
Italy & 97.8 & 2.2 & 0.0 & 0.0 & 100 \\
Spain & 79.0 & 16.4 & 4.6 & 0.0 & 100 \\
France & 92.2 & 7.1 & 0.7 & 0.0 & 100 \\
Austria & 92.5 & 7.2 & 0.3 & 0.0 & 100 \\
Germany & 93.0 & 6.8 & 0.2 & 0.0 & 100 \\
Netherlands & 89.2 & 9.5 & 1.3 & 0.1 & 100 \\
UK & 91.8 & 7.7 & 0.5 & 0.0 & 100 \\
Finland & 83.5 & 15.0 & 1.5 & 0.0 & 100 \\
Sweden & 95.5 & 4.5 & 0.0 & 0.0 & 100 \\
Norway & 89.6 & 9.6 & 0.8 & 0.0 & 100 \\
Czech Rep. & 85.3 & 14.3 & 0.4 & 0.0 & 100 \\
Japan & 97.9 & 2.0 & 0.2 & 0.0 & 100 \\
US & 41.8 & 30.4 & 16.4 & 11.4 & 100 \\
& & & & & \\
\hline
\end{tabular}

Source: Cheers 1999 and NLSY 1979-2002.

Note: If people were not working after a job, we counted this as a non-working spell. As a consequence, non-working spells are measured for those who have had at least one job. 
Table 3

Number of jobs held, variants of estimates

\begin{tabular}{|c|c|c|c|c|c|c|c|}
\hline & All & $\begin{array}{r}\text { Trunc. } 6 \\
\text { jobs } \\
\end{array}$ & $\begin{array}{c}\text { At least } \\
1 \text { job } \\
\end{array}$ & $\begin{array}{r}\text { age grad. } \\
<35 \\
\end{array}$ & $\begin{array}{r}\text { age grad. } \\
<30 \\
\end{array}$ & Women & Men \\
\hline Italy & 1.59 & & 1.62 & 1.61 & 1.62 & 1.61 & 1.57 \\
\hline Spain & 1.55 & & 1.74 & 1.55 & 1.56 & 1.60 & 1.48 \\
\hline France & 1.27 & & 1.37 & 1.28 & 1.28 & 1.26 & 1.28 \\
\hline Austria & 1.51 & & 1.56 & 1.52 & 1.53 & 1.55 & 1.47 \\
\hline Germany & 1.43 & & 1.48 & 1.43 & 1.42 & 1.42 & 1.45 \\
\hline Netherlands & 1.87 & & 1.92 & 1.89 & 1.90 & 1.90 & 1.84 \\
\hline UK & 1.77 & & 1.80 & 1.83 & 1.86 & 1.81 & 1.73 \\
\hline Finland & 1.75 & & 1.78 & 1.78 & 1.80 & 1.78 & 1.70 \\
\hline Sweden & 1.40 & & 1.46 & 1.42 & 1.42 & 1.41 & 1.38 \\
\hline Norway & 1.90 & & 1.95 & 1.93 & 1.94 & 1.87 & 1.95 \\
\hline Czech Rep. & 1.34 & & 1.40 & 1.34 & 1.34 & 1.28 & 1.42 \\
\hline Japan & 1.44 & & 1.44 & 1.44 & 1.44 & 1.50 & 1.38 \\
\hline US & 2.24 & 2.20 & 2.61 & 2.25 & 2.37 & 2.27 & 2.21 \\
\hline
\end{tabular}

Source: Cheers 1999 and NLSY 1979-2002.

Note: 'All' $=$ the average number of jobs for all graduates in the first three years after graduation. 'Trunc. 6 jobs' $=$ for the U.S., if people indicate to have had more than 6 jobs, we truncated the number of jobs to 6 . The result is the average number of jobs held given this condition. 'At least 1 job' = average number of jobs for those who had at least one job, 'age grad $<35$ ' = average number of jobs for respondents under 35 years of age at the moment of graduation, 'age grad $<30$ ' = average number of jobs for respondents under 30 years of age at the moment of graduation, 'Women/Men' = Average number of jobs for women, respectively men. 
Table 4

Variants of mobility

\begin{tabular}{lrrr}
\hline & $\begin{array}{r}\text { 3-Digit } \\
\text { changes }\end{array}$ & $\begin{array}{r}\text { Voluntary } \\
\text { separations }\end{array}$ & $\begin{array}{r}\text { Involuntary } \\
\text { separations }\end{array}$ \\
\hline & & & \\
Italy & 1.36 & 0.60 & 0.02 \\
Spain & 1.28 & 0.51 & 0.24 \\
France & 1.11 & 0.30 & 0.08 \\
Austria & 1.26 & 0.51 & 0.07 \\
Germany & -- & 0.44 & 0.07 \\
Netherlands & 1.52 & 0.83 & 0.10 \\
UK & 1.47 & 0.74 & 0.08 \\
Finland & 1.43 & 0.67 & 0.17 \\
Sweden & -- & 0.43 & 0.04 \\
Norway & 1.50 & 0.86 & 0.10 \\
Czech Rep. & 1.23 & 0.34 & 0.14 \\
Japan & 1.27 & 0.43 & 0.02 \\
US & 2.01 & 0.85 & 0.56 \\
& & & \\
\hline
\end{tabular}

Source: Cheers 1999 and NLSY 1979-2002.

Note: '3-digit changes' = the average number of jobs held given the condition that a job change is only counted if a change in the 3-digit occupational code is observed (Sweden and Germany are excluded because occupational codes were not available), 'Voluntary separation/involuntary separation' = the average number of job separations (as opposed to jobs held + jobs currently holding) with non-working spells after the job of 2 months or less for voluntary separations and more than 2 months for involuntary separations. 
Graph 1

Mobility pattern in Italy 1-36 months after graduation

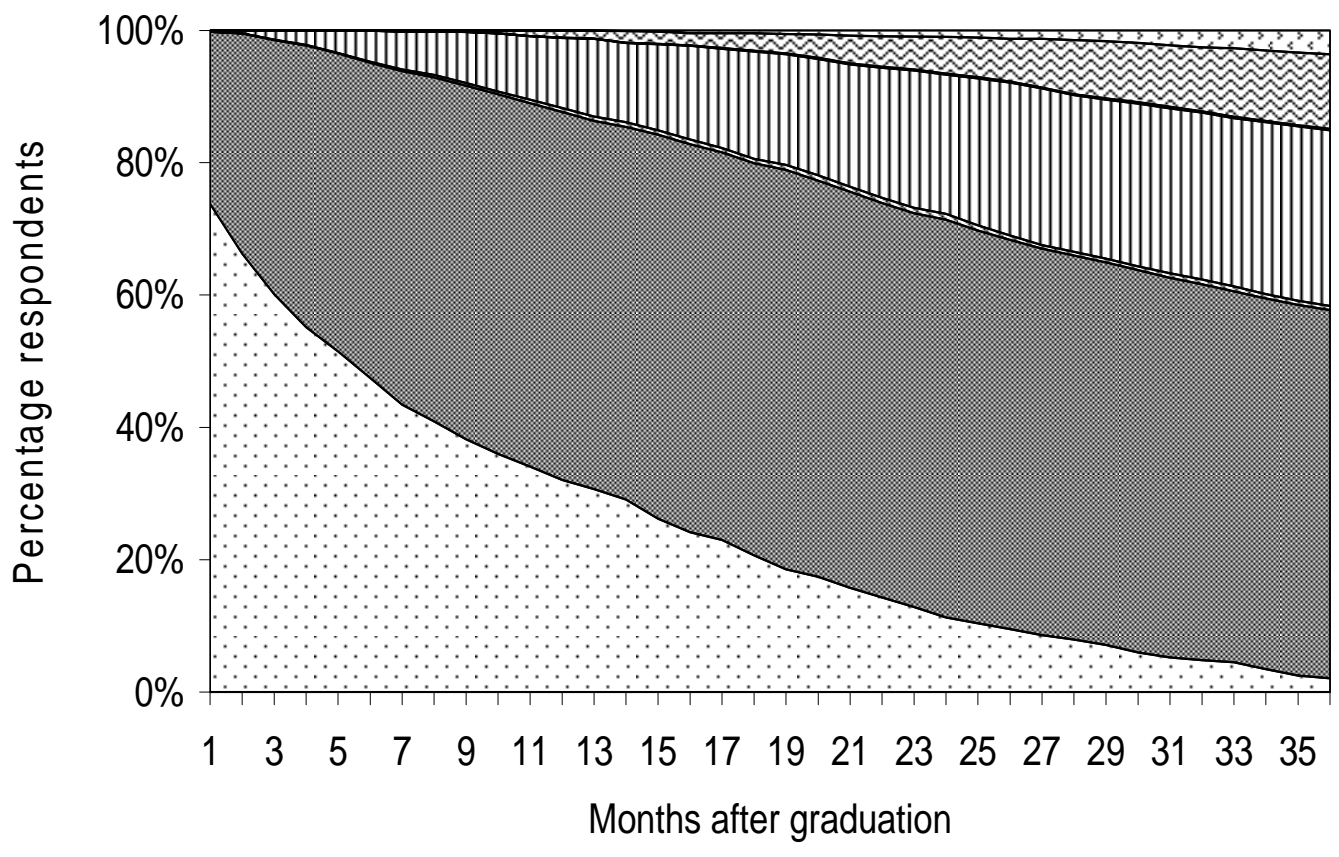

$\square$ No job bf 1st job $\quad$ 1st job

$\mathbb{N}$ No job aft 1st job $\square 2$ nd job

⿶No job aft 2nd job 园3rd job

강 job

Source: Cheers 1999. 
Graph 2

Mobility pattern in Spain 1-36 months after graduation

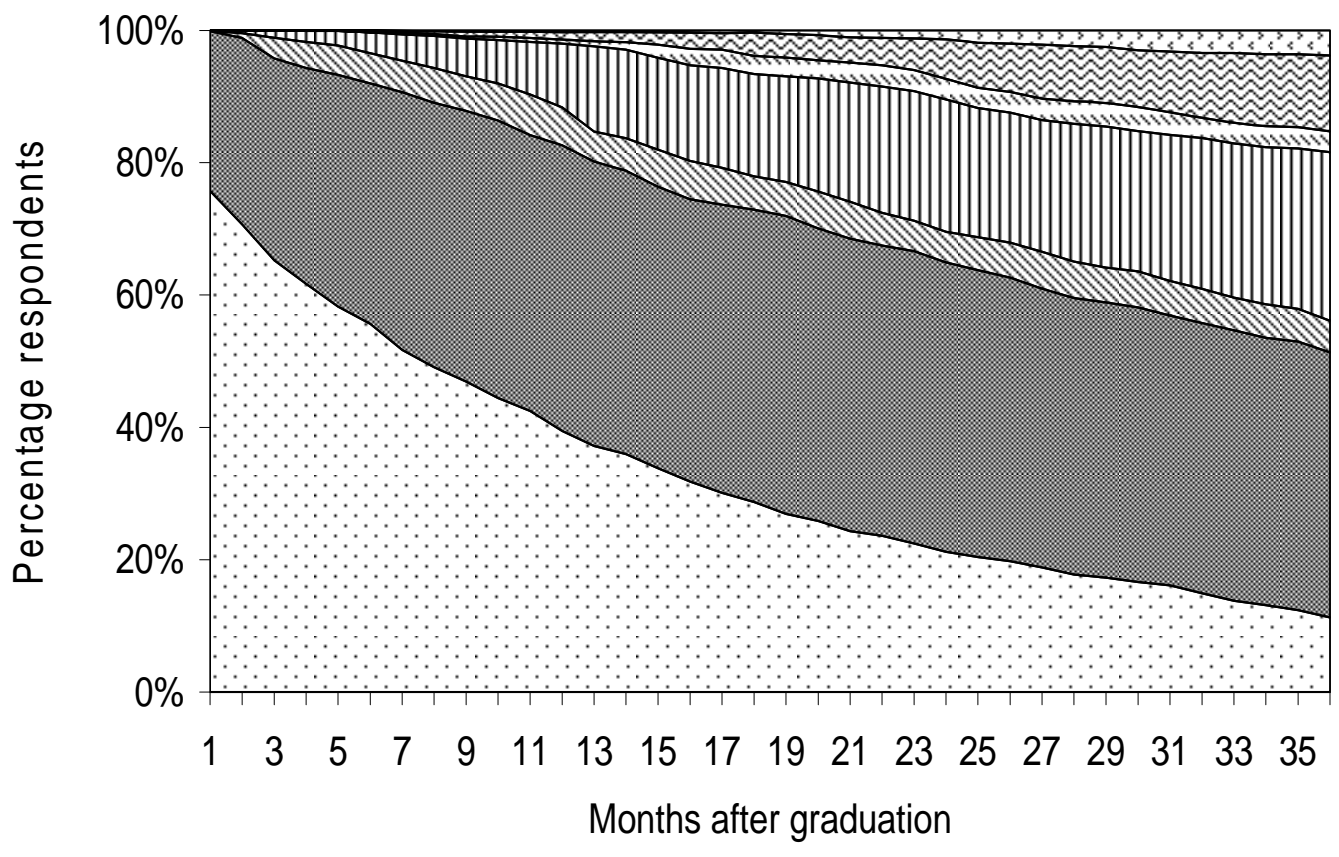

$\square$ No job bf 1st job $\quad$ 1st job No job aft 1st job ए2nd job

⿶No job aft 2nd job $\because 3 \mathrm{rd}$ job 강 job

Source: Cheers 1999. 
Graph 3

Mobility pattern in France 1-36 months after graduation

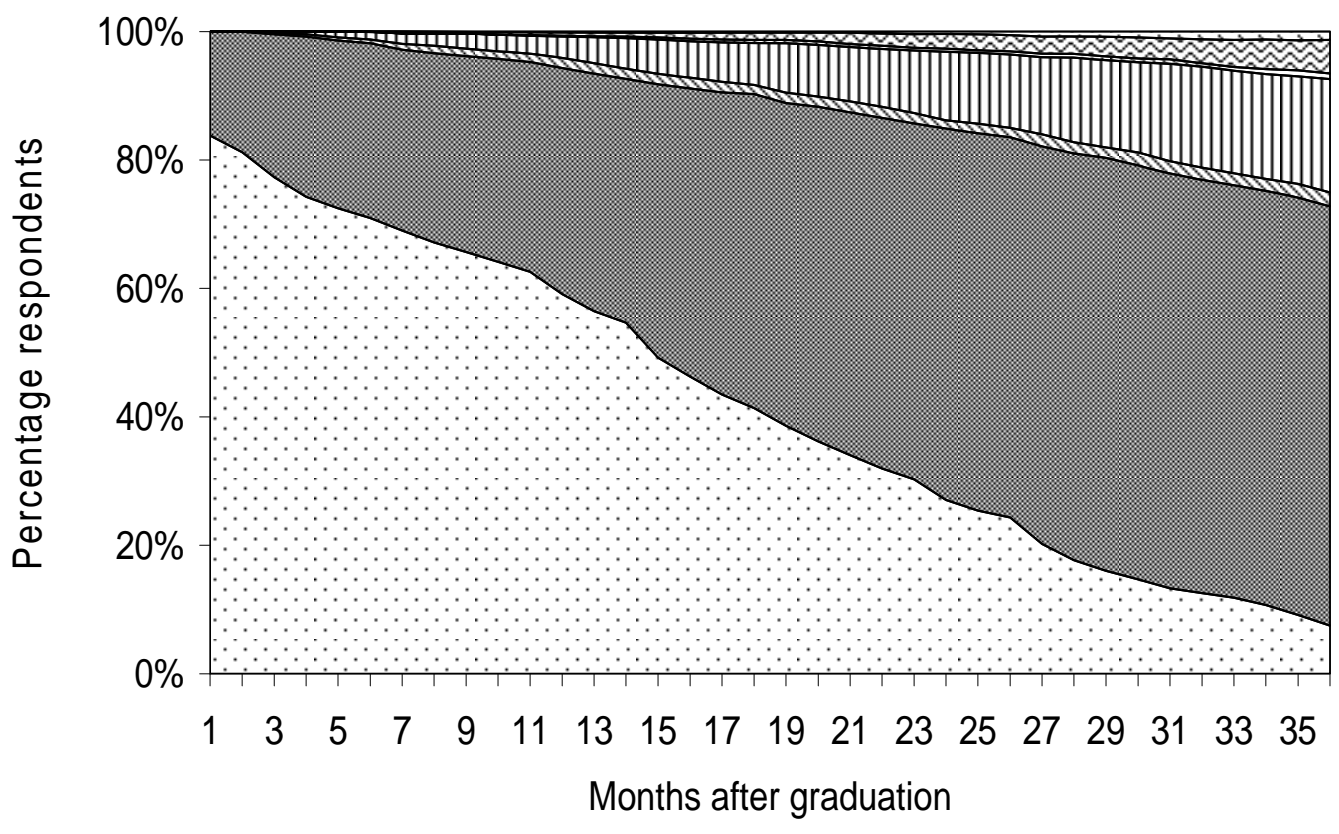

\begin{tabular}{|c|c|}
\hline $\begin{array}{l}\square \text { No job bf } 1 \text { st job } \square \text { 1st job } \\
\square \text { No job aft 2nd job } \because 3 r d \text { job }\end{array}$ & $\begin{array}{l}\text { No job aft 1st job } \square 2 \text { nd job } \\
\text { 4th job }\end{array}$ \\
\hline
\end{tabular}

Source: Cheers 1999. 
Graph 4

Mobility pattern in Austria 1-36 months after graduation

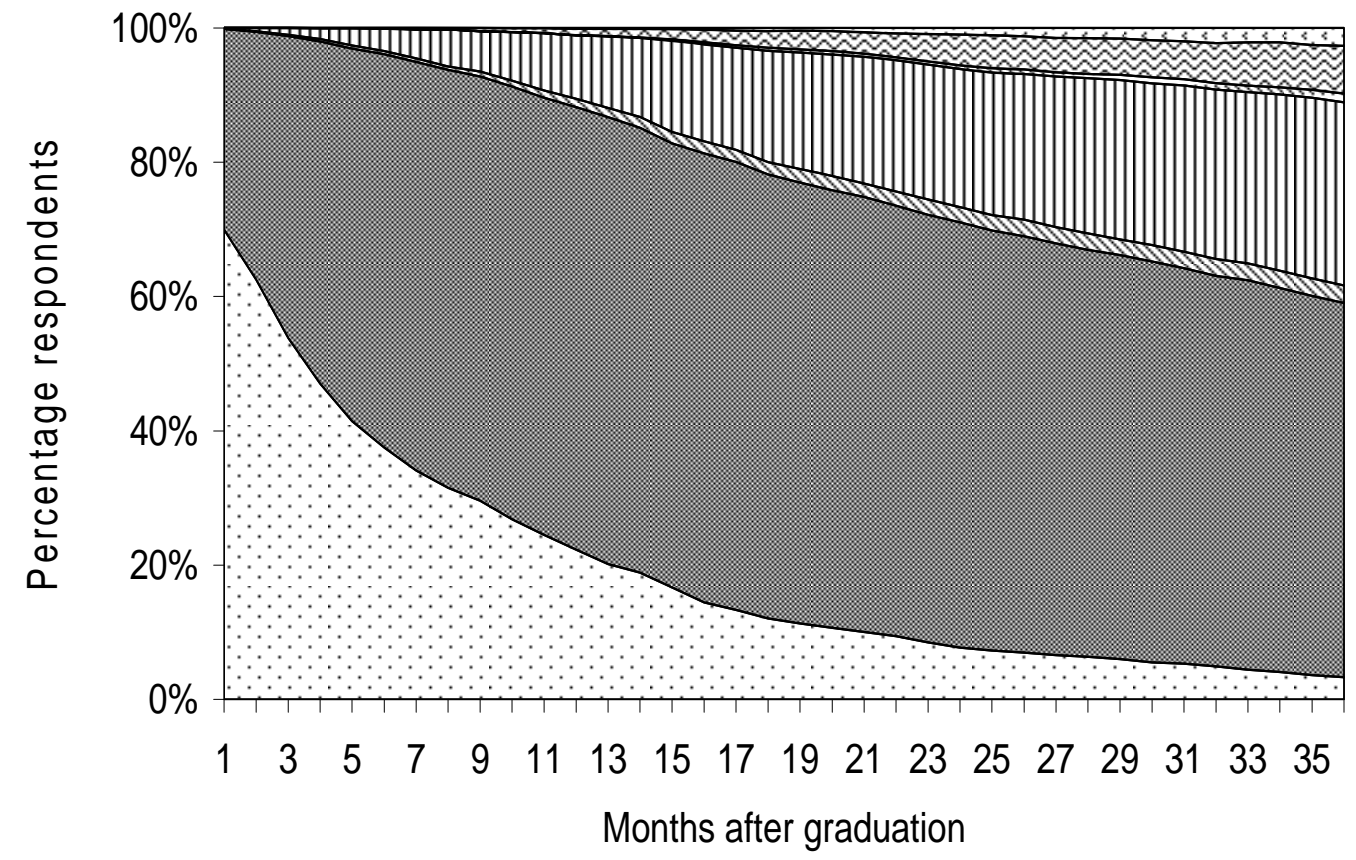

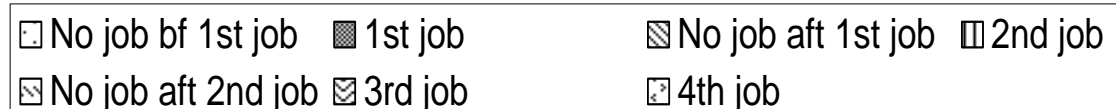

Source: Cheers 1999. 
Graph 5

Mobility pattern in Germany 1-36 months after graduation

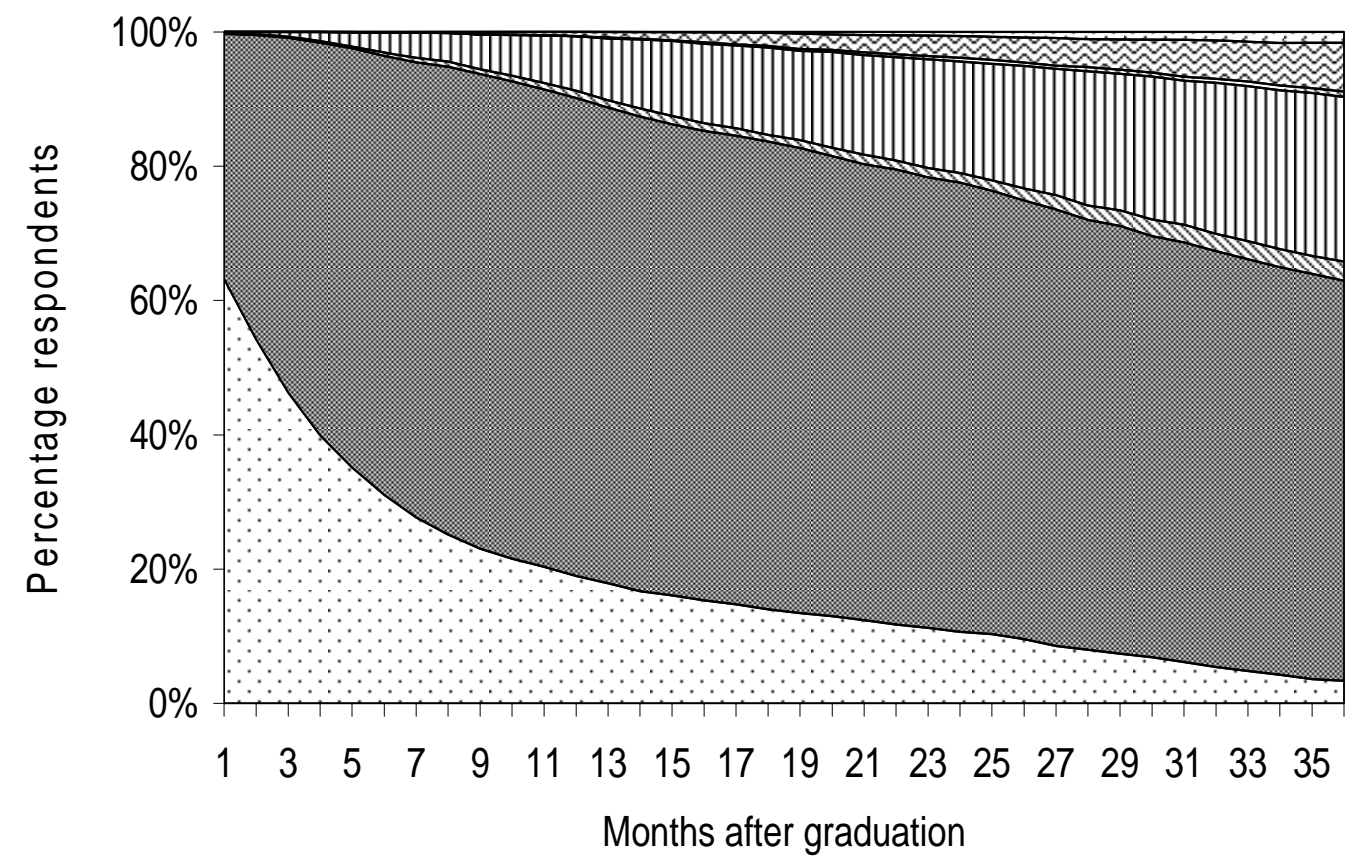

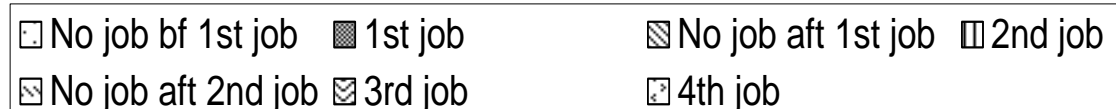

Source: Cheers 1999. 
Graph 6

Mobility pattern in the Netherlands 1-36 months after graduation

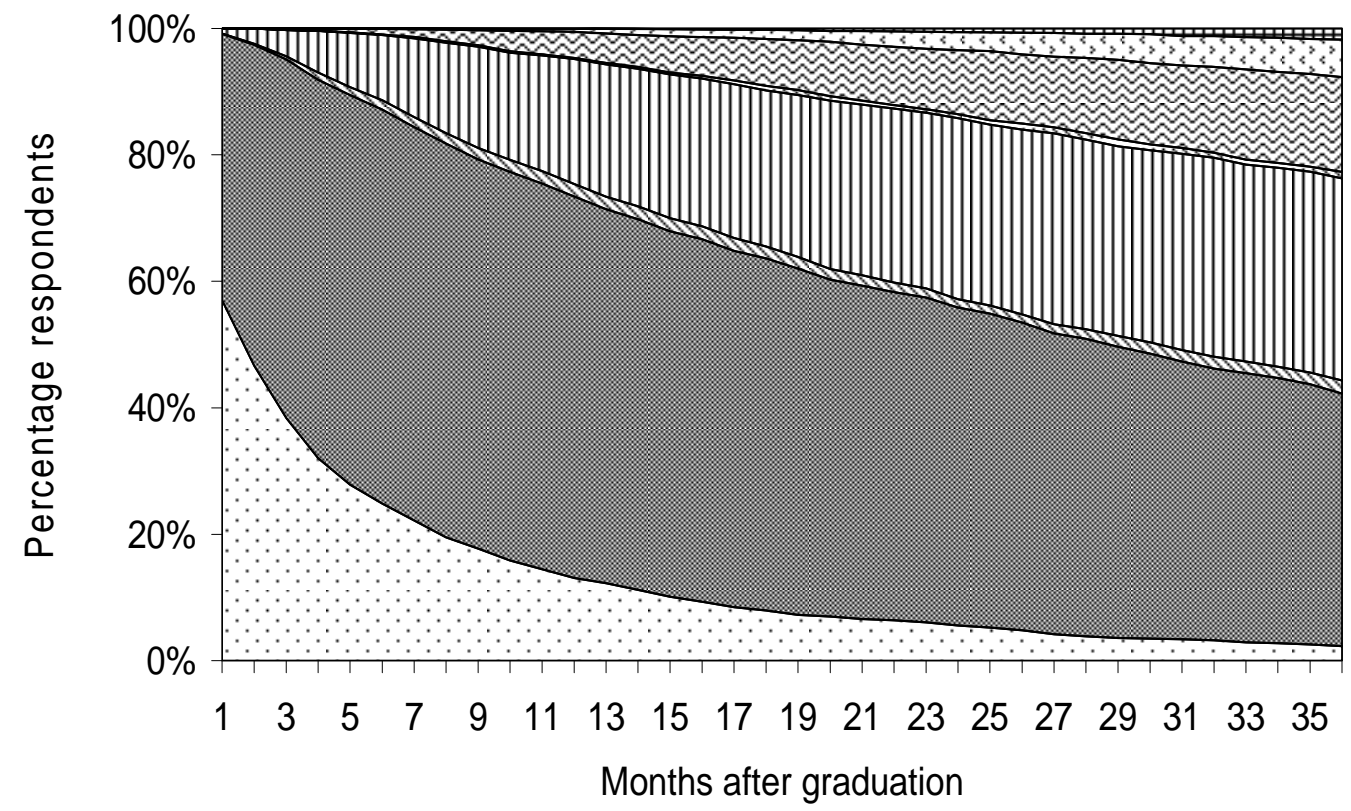

\begin{tabular}{|c|c|}
\hline$\square$ No job bf 1st job 1 st job & $\mathbb{N o}$ job aft 1st job $\square 2$ nd job \\
\hline
\end{tabular}

Source: Cheers 1999. 
Graph 7

Mobility pattern in the UK 1-36 months after graduation

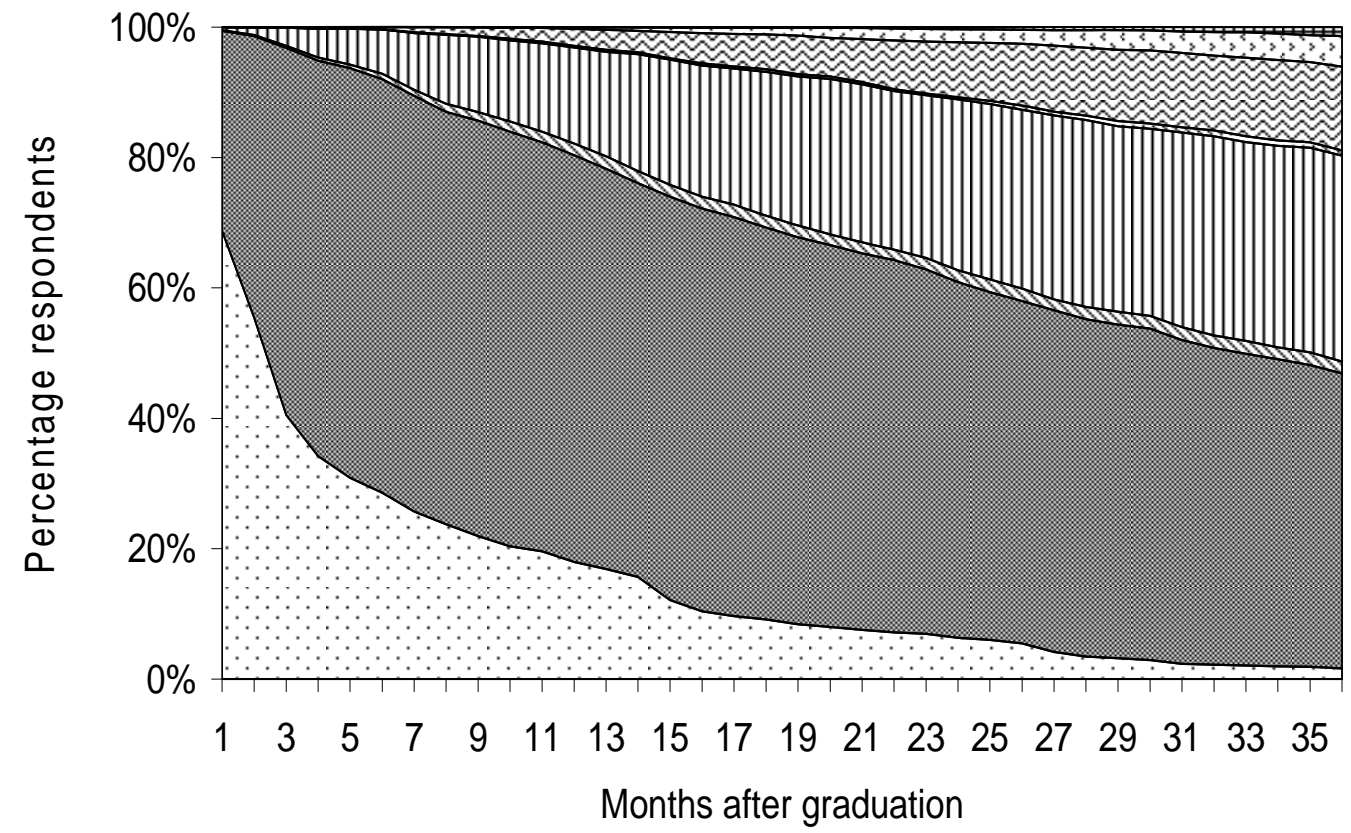

\begin{tabular}{|c|c|}
\hline$\square$ No job bf 1st job 1 st job & $\mathbb{N}$ No job aft 1st job $\square 2$ nd job \\
\hline
\end{tabular}

Source: Cheers 1999. 
Graph 8

Mobility pattern in Finland 1-36 months after graduation

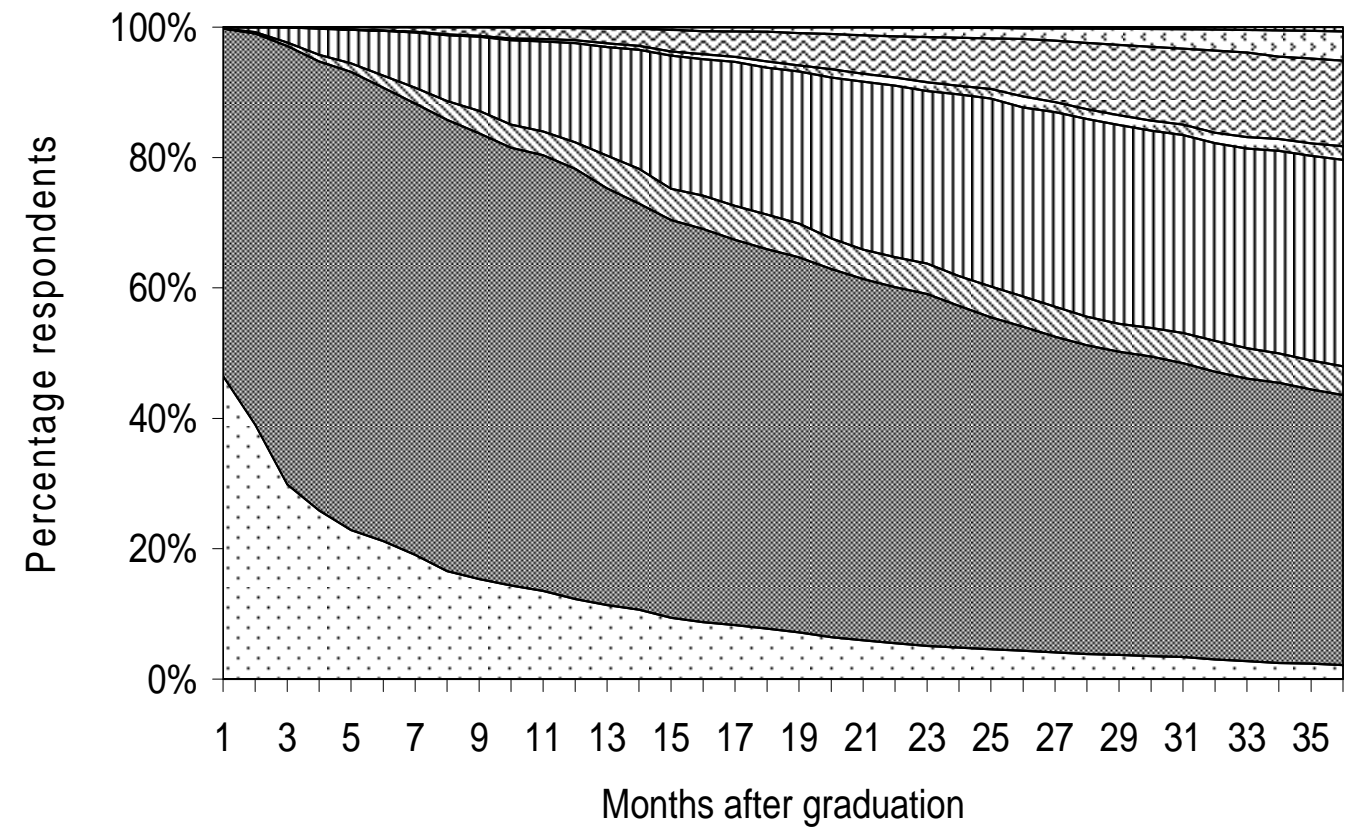

\begin{tabular}{|c|c|}
\hline$\square$ No job bf 1st job 1 st job & $\mathbb{N}$ No job aft 1st job $\square 2$ nd job \\
\hline
\end{tabular}

Source: Cheers 1999. 
Graph 9

Mobility pattern in Sweden 1-36 months after graduation

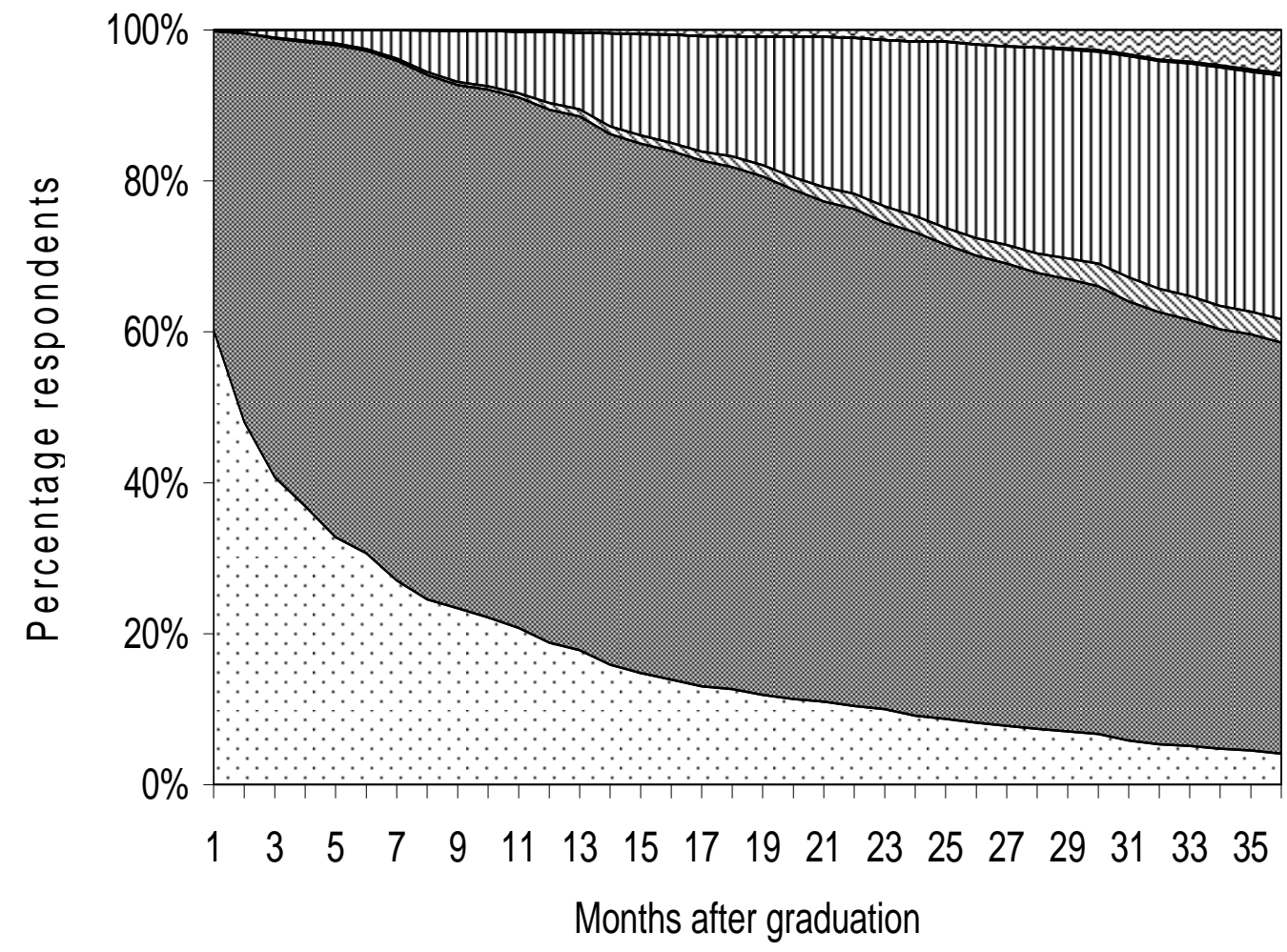

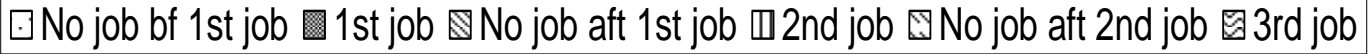

Source: Cheers 1999. 
Graph 10

Mobility pattern in Norway 1-36 months after graduation

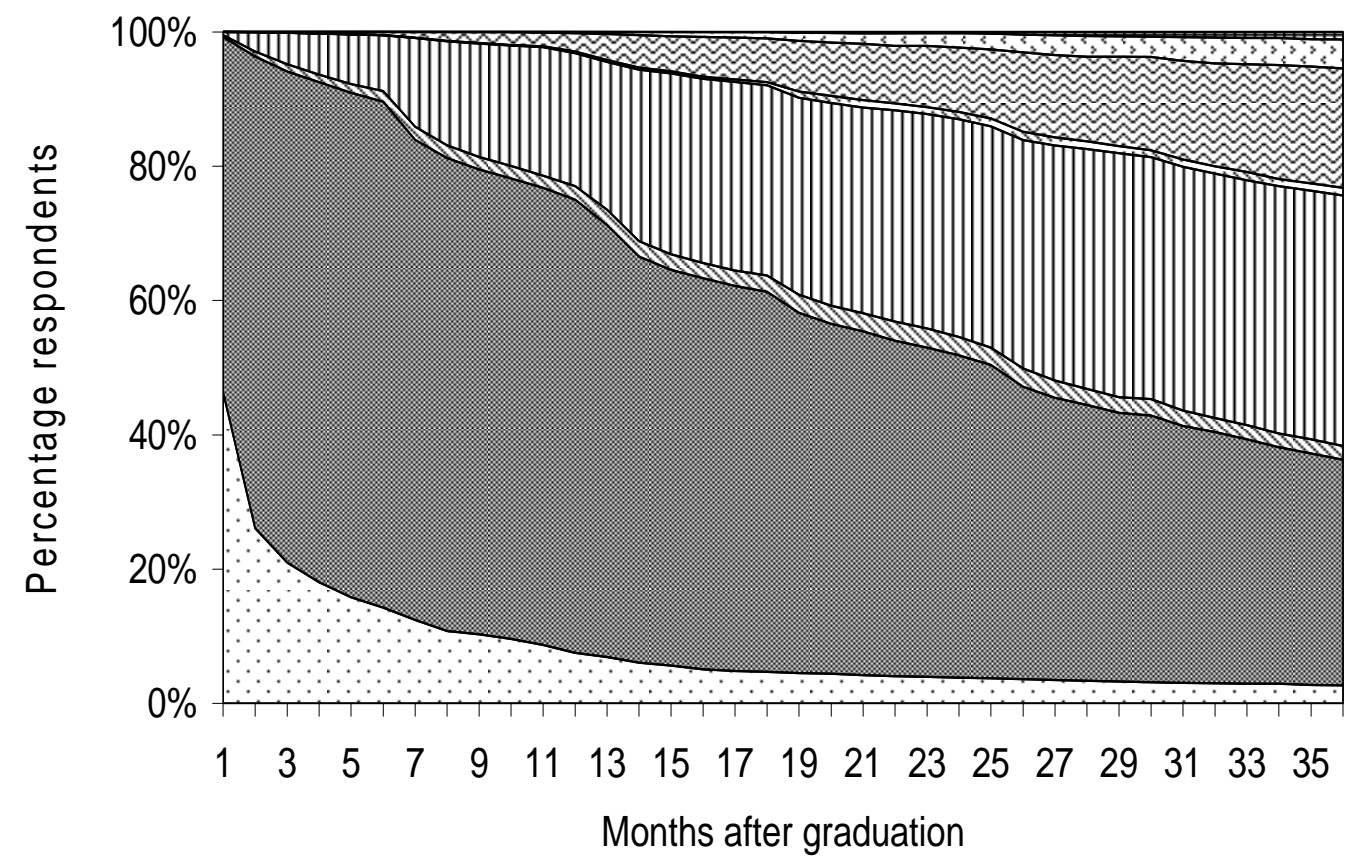

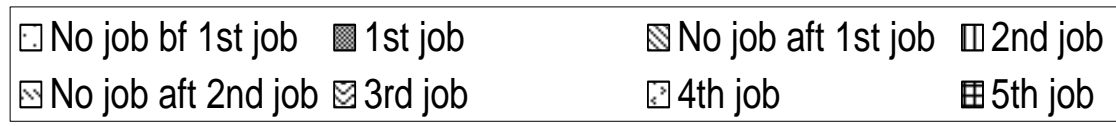

Source: Cheers 1999. 
Graph 11

Mobility pattern in the Czech Republic 1-36 months after graduation

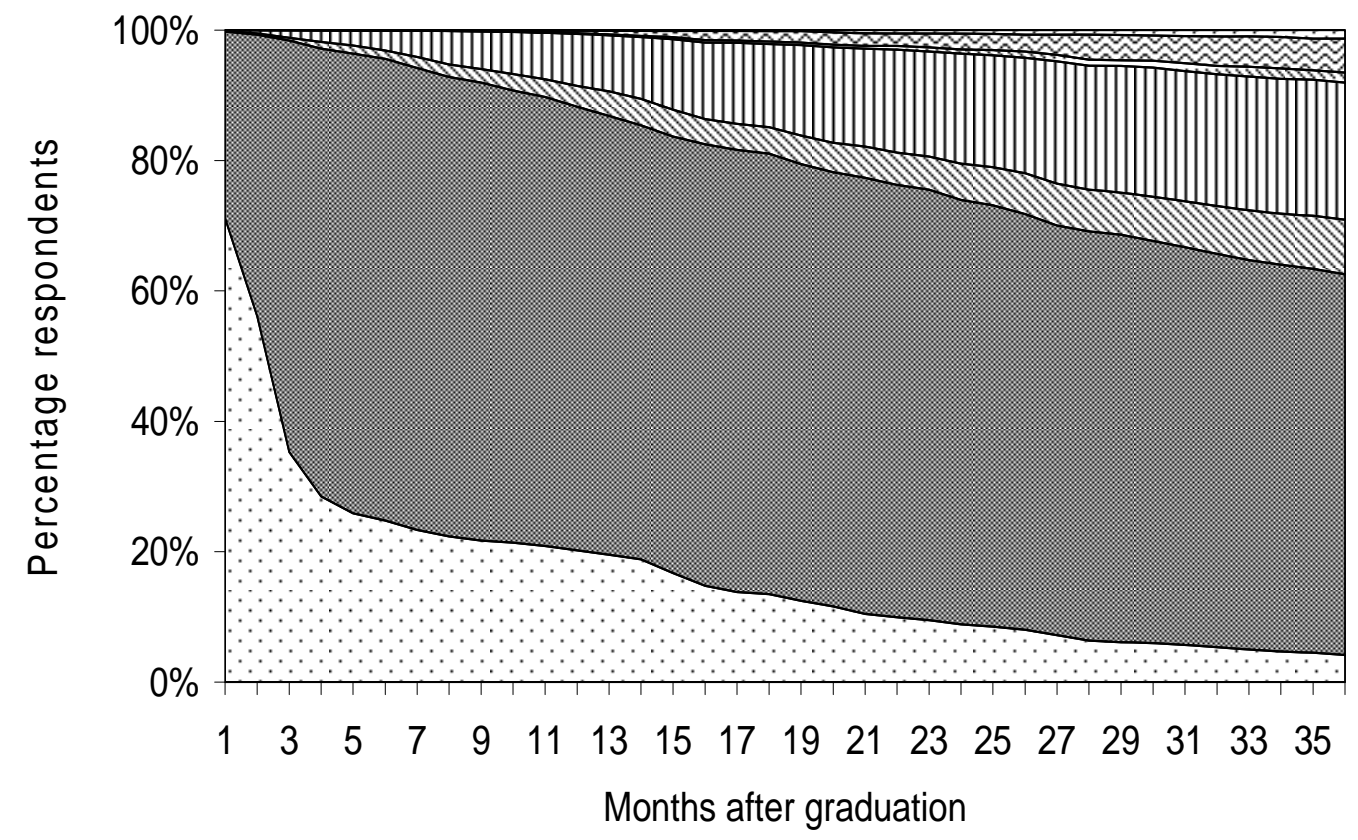

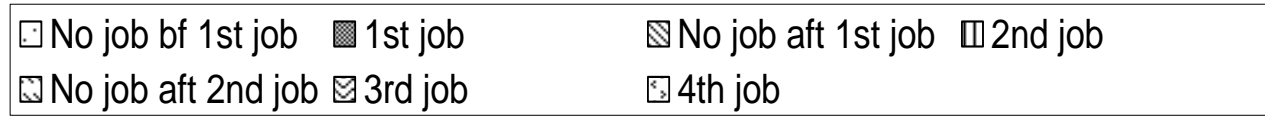

Source: Cheers 1999. 
Graph 12

Mobility pattern in Japan 1-36 months after graduation

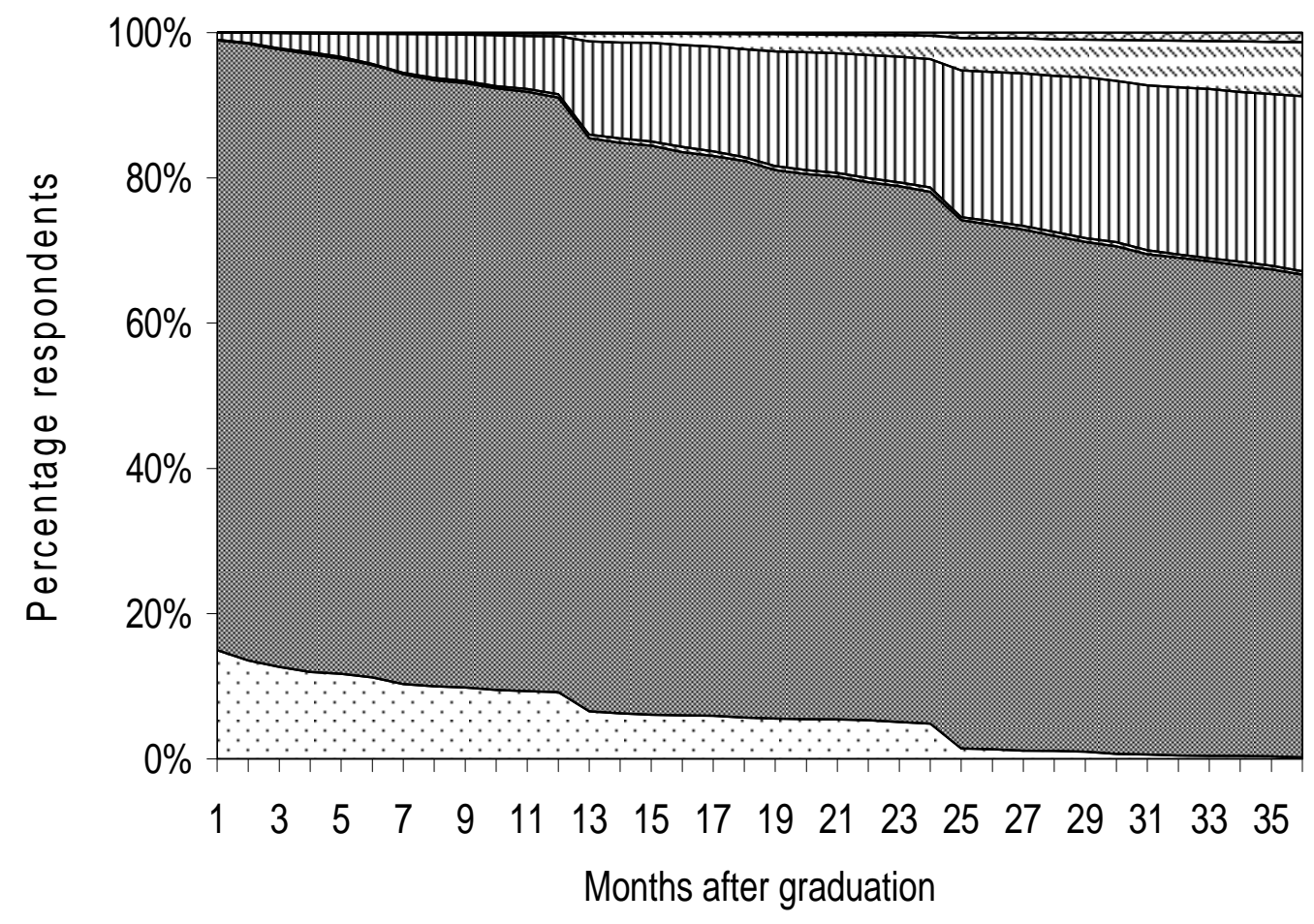

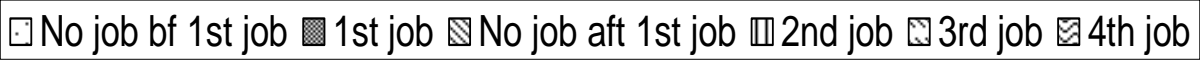

Source: Cheers 1999. 
Graph 13

Mobility pattern in the U.S. 1-36 months after graduation

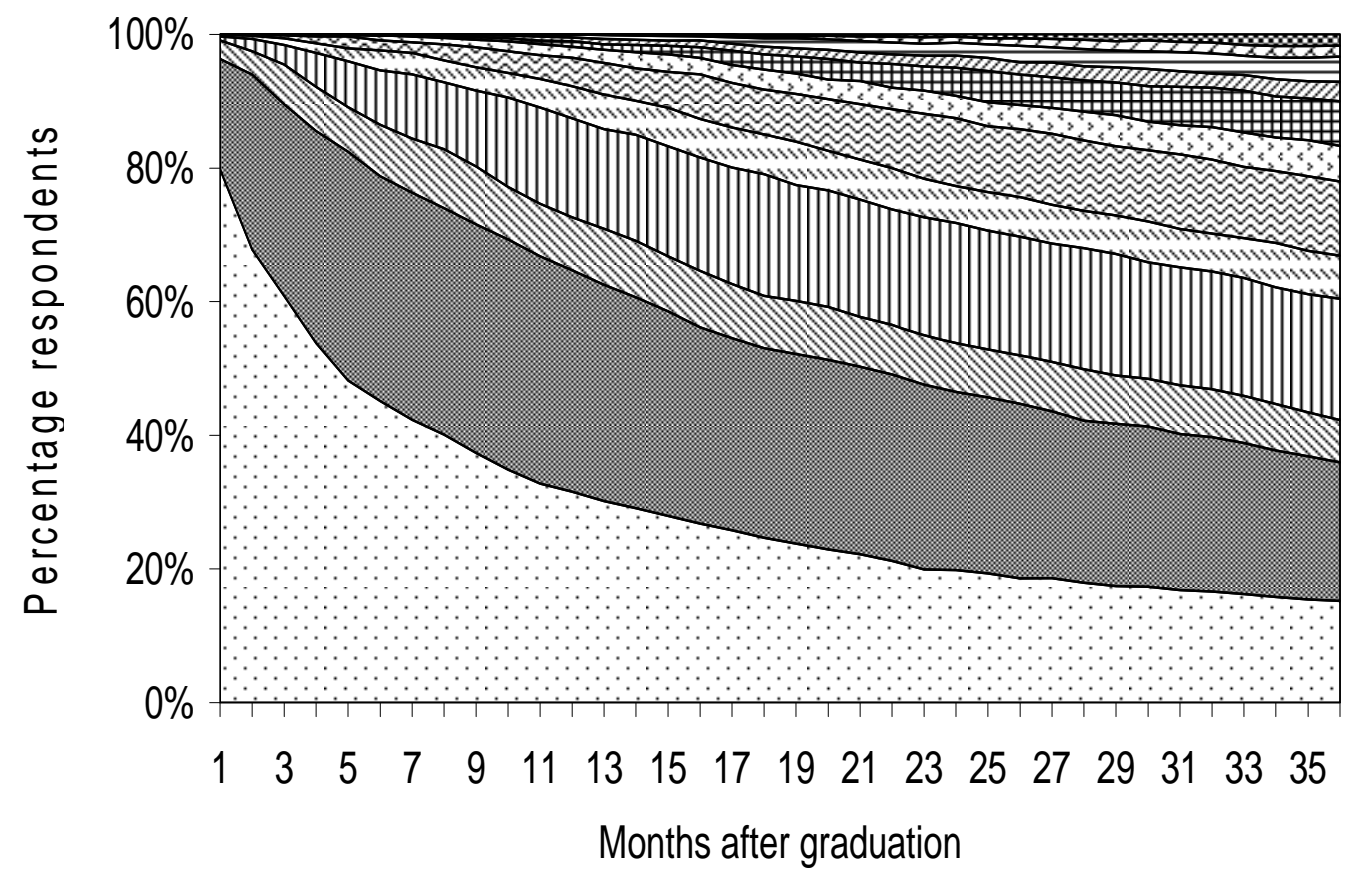

$\square$ No job bf 1st job \ 1st job \$No job aft 1st job $\square$ 2nd job No job aft 2nd job 园3rd job No job aft 3rd job 田4th job № job aft 4th job 目5th job $\checkmark$ No job aft 5th job $⿴ 6$ th job

Source: NLSY 1979-2002. 


\section{ENDNOTES}

\footnotetext{
${ }^{i}$ Many authors exclude temporary jobs, do their analysis only for white men, exclude military jobs, analyze longer time spans, exclude the first two jobs, look only at voluntary changes or only at displaced workers, etc.

ii They find, based on the NLSY, that white men have on average 1.23 job separations within two years after their entry to the labor market. This average increased to 2.53 separations after 4 years and 4.94 after 8 years. Note that job separations will be less than the number of jobs held (but not separated from), the number of which they report to be 5.5 in 8 years. As a rough estimate for the amount of jobs held after two and four years, we could add the difference between the job separations and the number of jobs held after eight years (0.56) to the reported separations after two years and four years. This leads to a number of jobs held after two years of 1.79 and of 3.09 after 4 years. Taking the average of these two years, the number of jobs held after 3 years would be around 2.44, which is a higher than our estimate of the sample of men probably because Light and McGarry (1998) do not only select college graduates.

iii The codes are not available for Germany and Sweden so we excluded these countries from the analysis.

iv The result in the U.S. is in line with the earlier shown result that non-employment between jobs is high in the U.S.

${ }^{v}$ If business cycles influence job changing, we should be able to see this in the differences in job changing per age group. We find some differences between the age groups in the NLSY but there are no systematic patterns that can be related to economic cycles.
} 